\title{
Dynamics of microbial communities during decomposition of litter from pioneering plants in initial soil ecosystems
}

\author{
J. Esperschütz ${ }^{1,2}$, C. Zimmermann ${ }^{3}$, A. Dümig ${ }^{4}$, G. Welzl ${ }^{2}$, F. Buegger ${ }^{5}$, M. Elmer ${ }^{6}$, J. C. Munch ${ }^{1,5}$, and M. Schloter ${ }^{2}$ \\ ${ }^{1}$ Technische Universität München - Chair of Soil Ecology Center of Life and Food Sciences Weihenstephan, Ingolstaedter \\ Landstr. 1, 85764 Neuherberg, Germany \\ ${ }^{2}$ Helmholtz Zentrum München, GmbH, German Research Center for Environmental Health Research Unit for Environmental \\ Genomics, Ingolstaedter Landstr. 1, 85764 Neuherberg, Germany \\ ${ }^{3}$ Brandenburg University of Technology Chair of Soil Protection and Recultivation, P.O. Box 101344, 03013 Cottbus, \\ Germany \\ ${ }^{4}$ Technische Universität München - Chair of Soil Science Center of Life and Food Sciences Weihenstephan, \\ Emil-Ramann-Straße, 85354 Freising, Germany \\ ${ }^{5}$ Helmholtz Zentrum München, GmbH, German Research Center for Environmental Health Institute of Soil Ecology, \\ Ingolstaedter Landstr. 1, 85764 Neuherberg, Germany \\ ${ }^{6}$ Brandenburg University of Technology Research Centre Landscape Development and Mining Landscapes, \\ Konrad-Wachsmann-Allee 6, 03046 Cottbus, Germany \\ Correspondence to: M. Schloter (schloter@helmholtz-muenchen.de)
}

Received: 14 September 2012 - Published in Biogeosciences Discuss.: 29 October 2012

Revised: 17 June 2013 - Accepted: 20 June 2013 - Published: 26 July 2013

\begin{abstract}
In initial ecosystems, concentrations of all macroand micronutrients can be considered as extremely low. Plant litter therefore strongly influences the development of a degrader's food web and is an important source for $\mathrm{C}$ and $\mathrm{N}$ input into soil in such ecosystems. In the present study, a ${ }^{13} \mathrm{C}$ litter decomposition field experiment was performed for 30 weeks in initial soils from a post-mining area near the city of Cottbus (Germany). Two of this region's dominant but contrasting pioneering plant species (Lotus corniculatus L. and Calamagrostis epigejos L.) were chosen to investigate the effects of litter quality on the litter decomposing microbial food web in initially nutrient-poor substrates. The results clearly indicate the importance of litter quality, as indicated by its $\mathrm{N}$ content, its bioavailability for the degradation process and the development of microbial communities in the detritusphere and soil. The degradation of the L. corniculatus litter, which had a low $\mathrm{C} / \mathrm{N}$ ratio, was fast and showed pronounced changes in the microbial community structure 1-4 weeks after litter addition. The degradation of the C. epigejos litter material was slow and microbial community changes mainly occurred between 4 and 30 weeks after litter addition to the soil. However, for both litter materials
\end{abstract}

a clear indication of the importance of fungi for the degradation process was observed both in terms of fungal abundance and activity $\left({ }^{13} \mathrm{C}\right.$ incorporation activity)

\section{Introduction}

Whereas initial terrestrial ecosystems are characterised by a dominance of geological processes like rock weathering, biological processes become increasingly important during ecosystem development (Gerwin et al., 2009). In this respect the role of pioneering plants colonising initial substrates are of high importance as they enhance carbon input into soil and influence the development of soil microbial communities. They drive the initial development of soil properties and food webs, mainly through root morphology, rhizodeposition and litter production (Bardgett, et al., 1999; Bardgett and Walker, 2004; Hättenschwiler et al., 2005). As the overall status of nutrients like ammonia and nitrate in initial ecosystems is low, plants benefit in turn from the microbial activities in soil, which act as catalysts of nutrient recycling from dead 
biomass and for the new input of nutrients (e.g. by nitrogen fixation) (Wardle et al., 2004).

In contrast to the degradation of root exudates, which has been considered as a very fast process, mainly driven by root associated microbes (Walker et al., 2003; Baudoin et al., 2003) that are more related to the plant species than to soil type, many authors have described two phases with highly differing kinetics during litter degradation (Dilly et al., 2003; Fioretto et al., 2005). Whilst initially easily degradable compounds derived from litter material are rapidly transformed mainly by epiphytic microbes, later stages of decay are dominated by the slower degradation of substances such as lignin and cellulose by soil microbes. After colonisation of litter by soil microbes, these form a complex network of interactions to catalyse microbial reactions involved in the decomposition of more recalcitrant litter components (Aneja et al., 2006). It has therefore been postulated that the later stage of litter degradation is mainly dependent on the structure and activity of soil microbes (Van Veen and Kuikman, 1990). Due to the importance of litter degradation for nutrient cycling in soil, many studies have been carried out in recent years to investigate the mobilization of carbon and other nutrients in different soil ecosystems, including forest stands (Moore-Kucera and Dick, 2008), agricultural fields (Elfstrand et al., 2008) or tropical soils (Kurzatokowski et al., 2004). Generally, degradation rates of litter were closely linked with the soil nitrogen content, confirming the hypothesis of Frey et al. (2003), who have postulated a reciprocal transfer of carbon and nitrogen at the soil litter interface.

However during the initial phase of soil ecosystem development, major biotic and abiotic parameters that have been considered as drivers for litter degradation differ from those in developed soils. The issue of how microbial activity commences in an "abiotic substrate" is a central question to restoration ecology. Therefore, to improve our understanding on litter degradation in initial soil ecosystems and to identify the underlying microbial network structures, we performed litter degradation studies using ${ }^{13} \mathrm{C}$-labelled litter from Lotus corniculatus L. and Calamagrostis epigejos L. These two plant species belong to two different plant families (Fabaceae, and respectively Poaceae), which are known to differ in their nutrient acquiring strategies and hence show consistent differences in litter stoichiometry (Fraser and Hockin, 2013). Both plant species have been noted as dominant members of the plant communities in post-mining areas (Pawlowska et al., 1997; Süß et al., 2004; Gerwin et al., 2009). The experiment was carried out on an experimental area close to an artificial catchment ("Chicken Creek"), located in an opencast mining area (Gerwin et al., 2009), where initial ecosystem processes as well as ecosystem development are being studied. To describe microbial communities involved in litter degradation and initial food web development, the ${ }^{13} \mathrm{C}$ contents of phospholipid fatty acids (PLFA) extracted from the soil were measured. We postulated that due to the initial nutrient-poor substrate that was associated with a low abundance of litter decomposers, the amount of $\mathrm{N}$ derived from plant litter significantly influences the abundance and activity of microbes involved in litter degradation, resulting in a much faster colonisation and degradation of the litter derived from L. corniculatus.

\section{Materials and methods}

\subsection{Plant litter labelling}

To obtain labelled plant litter, $2 \mathrm{~g}$ of Lotus corniculatus and $0.3 \mathrm{~g}$ of Calamagrostis epigejos seeds (BSV Saaten, Germany) were germinated in plastic pans $(12 \mathrm{~cm} \times 55 \mathrm{~cm} \times 35 \mathrm{~cm})$ using a mixture of potting soil, containing clay and silica sand $(2: 1: 1, v / v / v)$ in a greenhouse. Plants were grown at temperatures of $+20 /+15^{\circ} \mathrm{C}$ (day/night) and a relative humidity of between 75 and $85 \%$. Irrigation was performed daily via irrigation tubes $(500 \mathrm{~mL} / 24 \mathrm{~h})$. Biweekly, $500 \mathrm{~mL}$ of Hoagland-based fertilizer ( $25 \%$ strength) was added to each pan after irrigation (Hoagland, 1920). Three weeks after sowing, the plants were transferred into a tent (volume $\sim 7000 \mathrm{~L}$ ) made from airtight transparent plastic sheet material (Gschwendtner et al., 2011). Air recirculation was achieved using six fans, which were located in the tent corners and in the middle of the longitudinal sides of the tent. The air in the tent's atmosphere was subsequently replaced by artificial air containing isotopically labelled $\mathrm{CO}_{2}\left(\delta^{13} \mathrm{C}+170 \%\right.$ vs. Vienna-Pee Dee Belemnite (V-PDB), Air Liquide, Düsseldorf, Germany), and the $\mathrm{CO}_{2}$ within the tent was maintained between 350 and $400 \mu \mathrm{mol} \mathrm{mol}^{-1}$ (monitored by a photo-acoustic $\mathrm{CO}_{2-}$ controller, calibration at 300 to $600 \mu \mathrm{mol} \mathrm{mol}^{-1} \pm 2 \%$ ). Measurement of the ${ }^{13} \mathrm{C}$ atmosphere (three times a day) was conducted via Gas Chromatography Isotope Ratio Mass Spectrometry (GC-IRMS) analyses (Finnigan MAT 253, Bremen, Germany). Using this experimental set-up, an enriched ${ }^{13} \mathrm{C}$ atmosphere of $+140 \%$ V-PDB was established during plant growth. The labelled plants were harvested before flowering after a total growth time of six to eight weeks. Above-ground plant parts (stems and leaves) were oven-dried $\left(60^{\circ} \mathrm{C}\right)$, shredded $(0.5-2 \mathrm{~cm})$ and homogenised. The labelled plant litter of C. epigejos $\left(\delta^{13} \mathrm{C}=136.8 \pm 0.6 \%\right.$ o vs. V-PDB) and L. corniculatus $\left(\delta^{13} \mathrm{C}=101.3 \pm 2.1 \%\right.$ vs. VPDB) was used for the subsequent ${ }^{13} \mathrm{C}$ litter decomposition field study.

\subsection{Research site description}

The experiment was carried out in the post-mining area Welzow-Süd $\left(51^{\circ} 37^{\prime} 6^{\prime \prime} \mathrm{N}, 14^{\circ} 19^{\prime} 32^{\prime \prime} \mathrm{E}\right)$ close to the observation site "Chicken Creek" (Lausatia, Germany), where site observation started in September 2005 (Gerwin et al., 2009). The area is described as an area with temperate climate with sub-continental character, a mean annual temperature of $8.9^{\circ} \mathrm{C}$ and comparatively low precipitation $(563 \mathrm{~mm}$ 
per year). Soil texture was characterised as sands to loamy sands (sand $85 \%$, silt $9 \%$, clay $6 \%$ ). Soil nutrient content (e.g. for available nitrogen and phosphorous) was below or close to the detection limit $\left(<0.01 \mu \mathrm{g} \mathrm{g}^{-1}\right.$ soil). Major soil characteristics can be found in Table 1. Seed bank analyses showed only minor quantities of plant seeds, resulting in a low plant density of approximately 0.15 individuals per $\mathrm{m}^{2}$. Further meteorological data during the experimental period are shown in Fig. S1 and Table S1 (Supplement).

\subsection{Experimental set-up}

At the end of April 2009, tubes made of aluminium $(20 \mathrm{~cm}$ in diameter and $14 \mathrm{~cm}$ high) were installed $10 \mathrm{~cm}$ deep into the soil. Every treatment (control treatments without litter application $(\mathrm{Co})$, treatments with litter bags (Lb), treatments with direct litter application to soil (Ls)) was carried out in individual tubes for every time point $(1,2,4,15$ and 30 weeks). Additionally, one tube has been harvested at the beginning to represent the initial conditions (0) present at the start of the experiment. Hence, a total number of 26 tubes per field plot were replicated in five independent plots of $9 \mathrm{~m} \times 9 \mathrm{~m}$ across the experimental area. Due to a limited amount of plant litter available, litter bag treatments (Lb) only have been placed in four of the five independent plots. Every tube was protected against disturbances with steel grids on the top (mesh size $5 \mathrm{~mm}$ ). In Ls tubes, plant litter ( $5 \mathrm{~g}$, oven-dried) was mixed directly within the first $5 \mathrm{~cm}$ of the upper soil fraction.

The soil microbial community structure and selected soil parameters were investigated at several time points after the application of labelled plant litter material of $L$. corniculatus and C. epigejos. Water extractable organic carbon (WEOC) and microbial community structure based on its phospholipid fatty acids were investigated 1 week, 2 weeks, 4 weeks, 15 weeks and 30 weeks after the application of labelled plant litter in the detritusphere. The ${ }^{13} \mathrm{C}$ labelling was used to trace the $\mathrm{C}$ applied with the plant litter into the respective soil and microbial fractions. On every harvesting date, the detritusphere was harvested and sieved immediately $(<2 \mathrm{~mm})$ to remove litter residues from the soil substrate. An aliquot of around $50 \mathrm{~g}$ was immediately frozen at $-20^{\circ} \mathrm{C}$ for PLFA analyses, whereas the remaining amount was stored at $4{ }^{\circ} \mathrm{C}$ for further analyses described below. In addition, nylon litter bags $(10 \mathrm{~cm} \times 10 \mathrm{~cm}$; mesh size $40 \mu \mathrm{m})$ were filled separately with $L$. corniculatus and C. epigejos plant litter (5 g ovendried), and placed in separate tubes within the first $5 \mathrm{~cm}$. At every harvesting time point, one litter bag per plant litter treatment was removed to estimate litter decomposition rates.

\subsection{Soil parameters}

For analyses of total carbon (TC), total organic carbon (TOC), and $\delta^{13} \mathrm{C}$ of TC and TOC, as well as total nitrogen $(\mathrm{TN})$, dried soil aliquots $\left(60^{\circ} \mathrm{C}, 72 \mathrm{~h}\right)$ were ball- milled and subsequently weighed into tin capsules (approximately $70 \mathrm{mg}$ ) for elemental analysis and mass spectrometry. Inorganic $\mathrm{C}$ was estimated using a second set of samples in silver capsules, treated with $\mathrm{HCl}(30 \mu \mathrm{L}, 32 \%)$ with subsequent evaporation with a vacuum concentrator (Univapo $100 \mathrm{ECH}$, Montreal Biotech, Canada) at $50^{\circ} \mathrm{C}$ for $30 \mathrm{~min}$ prior to measurement. An additional tin capsule was put to each silver capsule to ensure an optimal combustion in the elemental analyser (Eurovector, Milan, Italy, coupled with an isotope ratio mass spectrometer, Delta V, Thermo Electron, Bremen, Germany). Samples were calibrated against the international standard USGS 40 . Soil $\mathrm{pH}$ was analysed in $0.01 \mathrm{M} \mathrm{CaCl}_{2}$ extracts (DIN ISO 10390). Prior to microbial and soil analyses, litter residues were carefully removed. However, depending on the weather conditions and especially the soil moisture in the top soil, a small proportion of plant litter material may have remained in the soil sample prior to extraction. The remaining litter residues in the soil samples have been quantified by light fraction analyses ( $>20 \mu \mathrm{m}$; Esperschütz et al., 2011) to be between 0.1 and $0.3 \%$ in all samples (data not shown).

\subsection{Litter bag analyses}

Litter degradation rates were calculated based on the loss of litter material in the litter bags during incubation after drying at $60^{\circ} \mathrm{C}$. The dried plant litter material was ball-milled and subsequently analysed for TOC, $\delta^{13} \mathrm{C}$ and TN content using an elemental analyser (Eurovector, Milan, Italy) coupled with an isotope ratio mass spectrometer (MAT 253, Thermo Electron, Bremen, Germany).

\subsection{WEOC and litter-derived ${ }^{13} \mathrm{C}$ in WEOC}

Aliquots of $5 \mathrm{~g}$ were taken in triplicates for the extraction of WEOC using $20 \mathrm{~mL}$ of $0.01 \mathrm{M} \mathrm{CaCl}_{2}$. Samples were shaken in a rotary shaker for $45 \mathrm{~min}$ and subsequently filtered through folded filters (595 1/2, Whatman GmbH, Germany) The extracts were stored at $-20^{\circ} \mathrm{C}$ until measurement. After acidification $(2 \mathrm{~N} \mathrm{HCl}, 30 \mu \mathrm{L})$, measurement of the total organic $\mathrm{C}$ (TOC) and $\delta^{13} \mathrm{C}$ in the $\mathrm{CaCl}_{2}$ extracts was done by online coupling of liquid chromatography and stable isotope ratio mass spectrometry (LC-IRMS, Thermo Electron, Bremen, Germany) according to Krummen et al. (2004) and Marx et al. (2007).

\subsection{PLFA analyses}

Phospholipid fatty acid (PLFA) analyses were performed based on Zelles et al. (1995). An aliquot of $50 \mathrm{~g}$ soil (dry weight) was extracted with $250 \mathrm{~mL}$ of methanol, $125 \mathrm{~mL}$ of chloroform and $50 \mathrm{~mL}$ of phosphate buffer $(0.05 \mathrm{M}, \mathrm{pH} 7)$. After $2 \mathrm{~h}$ of horizontal shaking, $125 \mathrm{~mL}$ of water and $125 \mathrm{~mL}$ of chloroform were added to promote phase separation. After $24 \mathrm{~h}$ the water phase was removed and discarded. The total lipid extract was separated into neutral lipids, glycolipids 
Table 1. Major soil parameters $(0-5 \mathrm{~cm}$ depth) of the soil substrate without litter application throughout the experimental period $(n=$ $5 \pm$ standard deviation).

\begin{tabular}{lllllll}
\hline & \multicolumn{5}{c}{ Harvesting time points 2009 } \\
\cline { 2 - 7 } $\begin{array}{l}\text { Soil } \\
\text { parameter }\end{array}$ & $\begin{array}{l}\text { April 29th } \\
\text { 0weeks }\end{array}$ & $\begin{array}{l}\text { May 06th } \\
\text { 1 week }\end{array}$ & $\begin{array}{l}\text { May 13th } \\
\text { 2 weeks }\end{array}$ & $\begin{array}{l}\text { May 26th } \\
\text { 4 weeks }\end{array}$ & $\begin{array}{l}\text { August 12th } \\
\text { 15 weeks }\end{array}$ & $\begin{array}{l}\text { November 30th } \\
\text { 30 weeks }\end{array}$ \\
\hline $\mathrm{pH}$ & $8.4 \pm 0.1$ & $8.4 \pm 0.1$ & $8.4 \pm 0.1$ & $8.5 \pm 0.1$ & $8.5 \pm 0.0$ & $8.3 \pm 0.1$ \\
TC [\%] & $0.42 \pm 0.33$ & $0.44 \pm 0.29$ & $0.47 \pm 0.33$ & $0.47 \pm 0.37$ & $0.44 \pm 0.31$ & $0.49 \pm 0.25$ \\
TOC [\%] & $0.26 \pm 0.10$ & $0.25 \pm 0.11$ & $0.22 \pm 0.08$ & $0.24 \pm 0.05$ & $0.30 \pm 0.12$ & $0.37 \pm 0.14$ \\
TN [\%] & $0.008 \pm 0.003$ & $0.009 \pm 0.004$ & $0.009 \pm 0.002$ & $0.009 \pm 0.003$ & $0.010 \pm 0.004$ & $0.009 \pm 0.004$ \\
$\mathrm{C}_{\text {org }}$ /N & $33.1 \pm 5.3$ & $29.3 \pm 8.1$ & $25.1 \pm 3.7$ & $26.6 \pm 5.3$ & $31.6 \pm 10.3$ & $42.2 \pm 13.7$ \\
$\delta^{13}$ C TOC & $-26.1 \pm 0.8$ & $-26.1 \pm 0.7$ & $-26.2 \pm 0.6$ & $-26.2 \pm 0.7$ & $-27.2 \pm 0.7$ & $-27.5 \pm 1.2$ \\
{$[\%$ vs. V-PDB] } & & & & & & \\
\hline
\end{tabular}

and phospholipids on a silica-bonded phase column (SPE-SI $2 \mathrm{~g} / 12 \mathrm{~mL}$; Bond Elut, Analytical Chem International, CA, USA). The phospholipid extract was further separated into saturated, monounsaturated and polyunsaturated fatty acids (see Zelles et al., 1995, for details) to facilitate the identification of fatty acids as well as to obtain a good baseline separation of peaks for isotopic calculations.

Prior to measurements, internal standards (nonadecanoic acid methyl ester and myristic acid methyl ester) were added to calculate absolute amounts of fatty acids. PLFA were analysed as fatty acid methyl esters (FAME) on a gas chromatograph/mass spectrometry system (5973MSD GC/MS Agilent Technologies, Palo Alto, USA). FAMEs were separated on a polar column (BPX-70, SGE GmbH, Griesheim, Germany), $60 \mathrm{~m} \times 0.25 \mathrm{~mm} \times 0.25 \mu \mathrm{m}$, coated with $70 \%$ of cyanopropyl polysilphenylene-siloxane (see Esperschütz et al., 2009, for details). The mass spectra of the individual FAME were identified by comparison with established fatty acid libraries (Solvit, CH 6500 - Luzern, Switzerland) using MSD Chemstation (Version D.02.00.237). The ${ }^{13} \mathrm{C}$ signature of the corresponding PLFA was determined by online coupling of the GC/MS system with an isotope ratio mass spectrometer (IRMS, Delta Advantage, Thermo Electron cooperation, Bremen, Germany) after combustion (GC Combustion III, Thermo Electron Cooperation, Bremen, Germany). The actual $\delta^{13} \mathrm{C}$ ratio of the individual FAME was corrected for the one $\mathrm{C}$ atom that was added during derivatisation (Abrajano et al, 1994). Fatty acids are presented by the number of $\mathrm{C}$ atoms followed by the number of double bonds. The positions of double bonds are indicated by " $\omega$ " and the number of the first double-bonded $\mathrm{C}$ atoms from the $\omega$ end of the $\mathrm{C}$ chain. Anteiso and iso-branched fatty acids are indicated by "a" and "i", followed by the number of $\mathrm{C}$ atoms. Branched fatty acids in which the position of the double bond was unknown were indicated by the prefix "br". Methyl groups on the tenth $\mathrm{C}$ atom from the carboxyl end of the molecule were indicated by "10ME". Cyclopropane fatty acids were indicated by the prefix "cy", while dicyclopropylic PLFA were indicated by "dic". Even-chained, saturated fatty acids were abbreviated with the prefix " $n$ ".

\subsection{Calculations}

Stable isotope results were expressed in $\delta^{13} \mathrm{C}$ or atom percent (AP); see Eqs. (1) and (2).

$\delta^{13} \mathrm{C}=\left[\left(R_{\text {sample }} / R_{\mathrm{V}-\mathrm{PDB}}\right)-1\right] x 1000$

${ }^{13} \mathrm{C}_{\mathrm{AP}}=(R /(R+1) x 100)$

$R_{\text {sample }}$ and $R_{\mathrm{V}-\mathrm{PDB}}$ represent the ${ }^{13} \mathrm{C}$ to ${ }^{12} \mathrm{C}$ ratios of sample and international standard Vienna-Pee Dee Belemnite (V-PDB $=0.0111802)$, respectively. The relative amount of litter-incorporated ${ }^{13} \mathrm{C}\left(\%{ }^{13} \mathrm{C}_{\text {LITTER }}\right)$ into the total lipid fraction or into the amount of WEOC was calculated according to Eq. (3).

$\%{ }^{13} \mathrm{C}_{\mathrm{LITTER}}=\mathrm{C}_{\mathrm{Tx}}\left({ }^{13} \mathrm{C}_{\mathrm{Tx}}-{ }^{13} \mathrm{C}_{T 0}\right) 100 /{ }^{13} \mathrm{C}_{\mathrm{added}}$,

where $\mathrm{C}_{\mathrm{Tx}}$ is the concentration of the individual $\mathrm{C}$ fraction $\left[\mathrm{ng} \mathrm{g}^{-1} \mathrm{DW}\right]$ at time point $\mathrm{Tx}$, which was multiplied by its ${ }^{13} \mathrm{C}$ enrichment in atom percent excess (difference between ${ }^{13} \mathrm{C}$ at time point $\mathrm{Tx}$ and ${ }^{13} \mathrm{C}$ enrichment at time point $T 0$ ) and expressed relative to the amount of ${ }^{13} \mathrm{C}_{\text {added }}$ [ng g $\left.{ }^{-} 1 \mathrm{DW}\right]$. The relative ${ }^{13} \mathrm{C}$ distribution within total measured phospholipids $\left(\%{ }^{13} \mathrm{C}_{\mathrm{DIST}}\right)$ was calculated as follows:

$\%{ }^{13} \mathrm{C}_{\text {DIST }}=\%{ }^{13} \mathrm{C}_{\text {LITTER }} i 100 / \sum \%{ }^{13} \mathrm{C}_{\text {LITTER }} i$,

where $\%{ }^{13} \mathrm{C}_{\text {LITTER }} i$ represents the relative amount of added ${ }^{13} \mathrm{C}$ in an individual phospholipid $i$.

\subsection{Statistics}

A two-way analysis of variance (ANOVA) was performed to establish significant interactions between the harvesting time ( 0 weeks, 1 week, 2 weeks, 4 weeks, 15 weeks and 30 weeks) 
and treatment (control, L. corniculatus and C. epigejos). Significant differences for specific variables were identified using a Duncan's post-hoc test at $p<0.05$ following a one-way ANOVA. Exponential curve-fitting (Fig. 2) was performed with Sigma Plot 11.2 (Systat software Inc.). Data illustration was performed with Adobe Illustrator CS3 and S-PLUS 8.1 (Tibco Software Inc.). Results are presented as means $(n=5)$ with standard deviations given in brackets.

Soil microbial community profiles were analysed using principal response curves (PRCs). This method was originally suggested to study the effect of different treatments on ecological communities with repeated observations in time (van den Brink and ter Braak, 1999). PRCs can be interpreted as a special case of redundancy analysis (function pre in library vegan, R-project). It has been shown (Schramm et al., 2007) that a PRC is equivalent to a two-step procedure, which involves the transformation of data (centring with respect to time and averaging according to treatment groups) and a principal component analysis with the transformed data. Results of this method reveal contrasts to a specified treatment group (normally the control group), and coefficients are plotted against time. A permutation test on the between-group variance (R-package ade4) was used to test for differences in the community profile of the control and treated group. Moreover, variable scores describe the relative weight of each variable for the component and can be used to identify significant variables. Using the R environment for statistical computing (http://www.R-project.org), this algorithm was used to generate Figs. 3, 4, and 5.

\section{Results}

\subsection{Plant litter degradation}

Both plant litter types were degraded during the experimental period of 30 weeks (Fig. 1); faster degradation rates were observed for litter material of $L$. corniculatus over the whole experimental period. At the final sampling, significantly more litter material from C. epigejos $(50 \%)$ than L. corniculatus $(30 \%)$ remained undegraded (Table 2 ). For both litter types, degradation rates in the first four weeks after application were higher compared to the degradation rates observed after 30 weeks of incubation. The $\mathrm{N}$ content of $L$. corniculatus liter was significantly higher compared to C. epigejos plant litter, which resulted in a $\mathrm{C} / \mathrm{N}$ ratio of around 40 for $C$. epigejos compared to 15 for $L$. corniculatus. While the $\mathrm{C} / \mathrm{N}$ ratio of L. corniculatus did not change over the experimental period, there was a marked decrease of $C$. epigejos litter with a $\mathrm{C} / \mathrm{N}$ ratio of 25 after 30 weeks.

\subsection{WEOC, microbial biomass and litter-derived ${ }^{13} \mathrm{C}$}

The WEOC content in soil significantly increased after only one week for both litter types compared to control soil (Fig. 2; Table 2), indicating a rapid release of easily degrad-
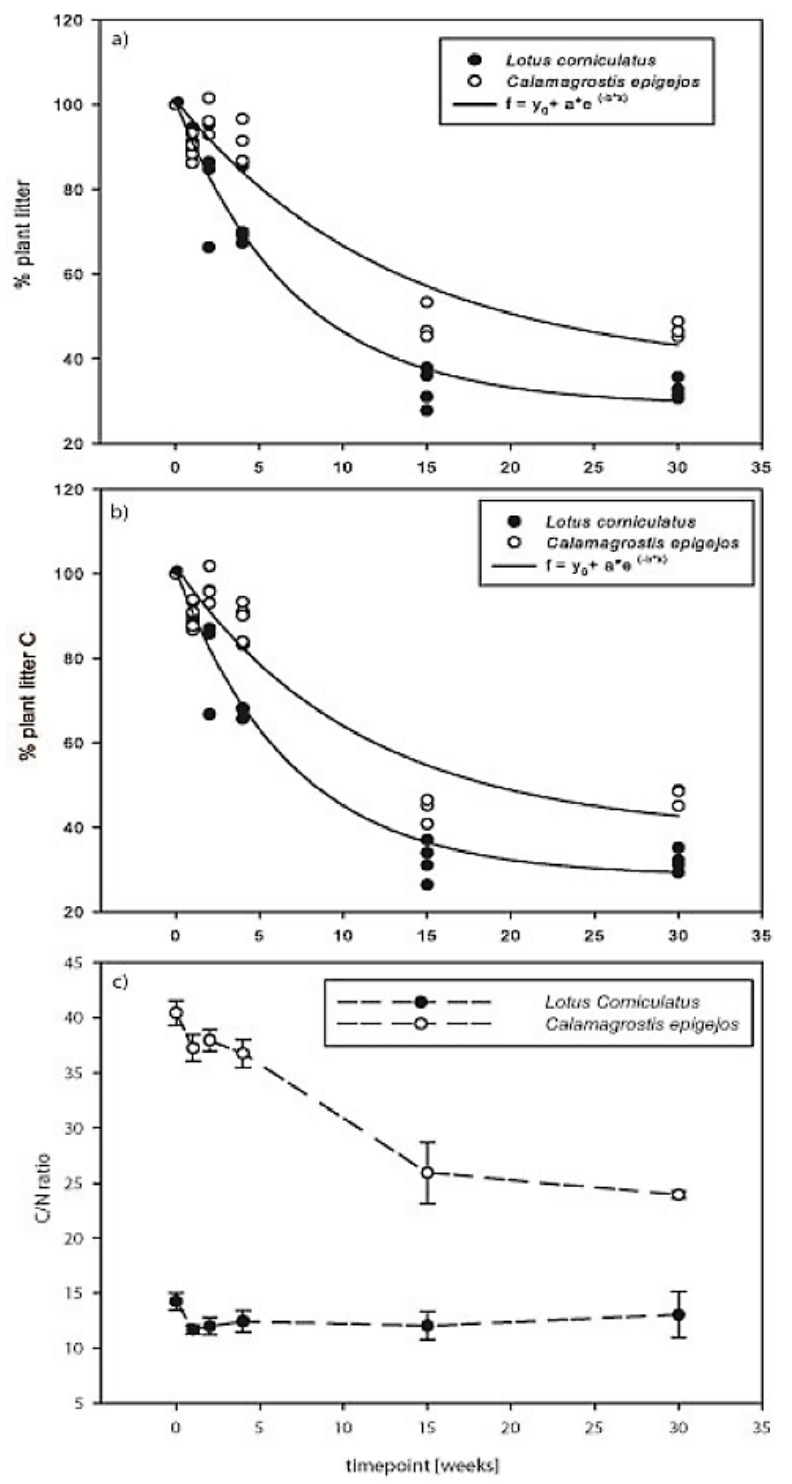

Fig. 1. Total mass loss (a), $\mathrm{C}$ loss (b) and $\mathrm{C} / \mathrm{N}$ ratio (c) of the plant litter throughout the experiment. Results are presented as single values $(\mathbf{a}, \mathbf{b})$ or means \pm standard deviation (c) based on four replicates.

able substances from litter material. At that time point in the $L$. corniculatus treatments, a 2.5 fold higher WEOC content was detected compared to the soil samples which were treated with C. epigejos litter $\left(250 \mathrm{mg} \mathrm{kg}^{-1} \mathrm{dw}\right.$ compared to $100 \mathrm{mg} \mathrm{kg}^{-1} \mathrm{dw}$ ). This high amount of WEOC decreased sharply in both treatments and was comparable to the control treatments after 15 weeks of litter incubation for both plant litter types. Incorporation of ${ }^{13} \mathrm{C}$ followed the same trend and confirmed that the increase of WEOC in the first weeks of incubation originated from the litter material (Fig. 2c).

Soil microbial biomass was estimated on the basis of total PLFA. The application of L. corniculatus plant litter stimulated total microbial biomass during the first four weeks 
Table 2. Adjusted $p$ values for the plant species effect as revealed with a 2-way ANOVA for each time point (Figs. 2 and 3). Significant differences are indicated by bold numbers $(p \leq 0.05)$.

\begin{tabular}{lrrrrr}
\hline & Week 1 & Week 2 & Week 4 & Week 15 & Week 30 \\
\hline C / N & $<\mathbf{0 . 0 0 1}$ & $<\mathbf{0 . 0 0 1}$ & $<\mathbf{0 . 0 0 1}$ & $<\mathbf{0 . 0 0 1}$ & $<\mathbf{0 . 0 0 1}$ \\
\% plant litter & 0.188 & 0.095 & 0.051 & $\mathbf{0 . 0 0 5}$ & $<\mathbf{0 . 0 0 1}$ \\
\% plant litter C & 1.000 & 0.193 & $\mathbf{0 . 0 2 6}$ & $\mathbf{0 . 0 1 7}$ & $<\mathbf{0 . 0 0 1}$ \\
WEOC mg kg $^{-1}\left(\log _{10}\right)$ & $<\mathbf{0 . 0 0 1}$ & $<\mathbf{0 . 0 0 1}$ & $<\mathbf{0 . 0 0 1}$ & 0.923 & 0.118 \\
\% added ${ }^{13} \mathrm{C}$ in WEOC $\left(\log _{10}\right)$ & $\mathbf{0 . 0 3 1}$ & 1.000 & $\mathbf{0 . 0 0 5}$ & 1.000 & 1.000 \\
PLFA $_{\text {total }} \mathrm{mg} \mathrm{kg}^{-1}\left(\log _{10}\right)$ & $<\mathbf{0 . 0 0 1}$ & $<\mathbf{0 . 0 0 1}$ & $<\mathbf{0 . 0 0 1}$ & $\mathbf{0 . 0 0 7}$ & $\mathbf{0 . 0 2 7}$ \\
\% added ${ }^{13} \mathrm{C}$ in PLFA $\left(\log _{10}\right)$ & $<\mathbf{0 . 0 0 1}$ & $<\mathbf{0 . 0 0 1}$ & $<\mathbf{0 . 0 0 1}$ & 0.874 & $\mathbf{0 . 0 0 2}$ \\
\hline
\end{tabular}
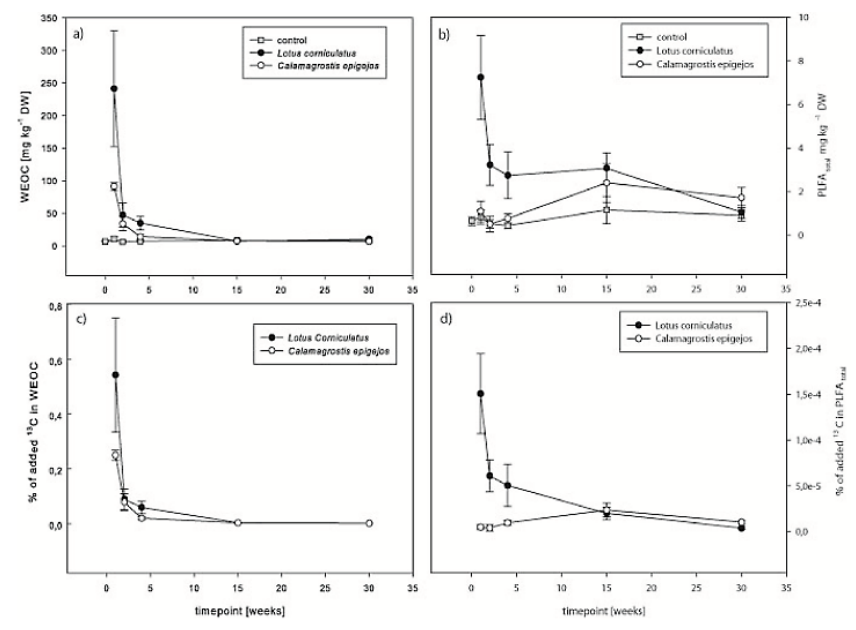

Fig. 2. WEOC (a) and soil microbial biomass (b) based on total PLFA in L. corniculatus and C. epigejos treatments. Relative amount of litter-derived ${ }^{13} \mathrm{C}$ in WEOC (c) and soil microbial biomass (d); values are expressed as a percentage of initially added ${ }^{13} \mathrm{C}$, normalised with controls. Results are shown with standard deviations $(n=5)$.

of the experimental period with maximum values one week after litter application (Fig. 2b). In contrast, no significant increase was observed in the C. epigejos treatments. Only 15 weeks after litter application, the microbial biomass in C. epigejos was slightly increased, compared to the control treatments. Again, similar results were observed following the ${ }^{13} \mathrm{C}$ signature over time (Fig. $2 \mathrm{~d}$ ).

\subsection{Soil microbial community profile and ${ }^{13} \mathrm{C}$ incorporation}

Litter type had a pronounced influence on the structure of the microbial litter degrader community as indicated by principal response curves of both litter types (global test: $p<0.001$ ). In the L. corniculatus treatment, component 1 and 2 accounted for $61.6 \%$ and $35.1 \%$ of the total variance 1 week after litter application (Fig. 3; Table 2). Significant differences were detected for the time points 1 week, 2 weeks and 4 weeks after litter application. For these time points higher proportions of the fatty acid $18: 3$ were detected compared to the control treatments. Component 1 was dominated by this variable. Four weeks after litter application, there was an additional effect with higher proportions of PLFAs $18: 2 \omega 6,9$ and a15:0. Differences were low compared to the control treatments at the last sampling time points 15 and 30 weeks after litter application.

In $C$. epigejos treatments component 1 accounted for $69.1 \%$, and component 2 for $20.3 \%$, of the total variance (Fig. 4; Table 2). Significant differences were found 4 weeks (component 1) and 30 weeks (component 2) after litter application. Most pronounced was a large increase of PLFA $18: 2 \omega 6,9$ four weeks after litter application compared to the control samples; slightly higher proportions of a15:0 were also observed. During this period, several PLFAs were reduced compared to the control soils (e.g. n24:0, n22:0, $\mathrm{n} 20: 0, \mathrm{n} 16: 0)$. At the end of the experiment the PLFA profile was dominated by $18: 2 \omega 6,9,18: 3,18: 1 \omega 7$ and $16: 1 \omega 7$.

The ${ }^{13} \mathrm{C}$ signature of the corresponding PLFA was used to identify the active part of the microbial community involved in the litter degradation. L. corniculatus and C. epigejos treatments were compared in a PRC based on the percentage distribution of litter-derived ${ }^{13} \mathrm{C}$ among individual PLFAs. The results clearly indicate significant differences in response to the litter type and time points under investigation (global test, $p<0.001$ ). Overall, components 1 and 2 could explain $75.2 \%$ and $21 \%$ of the total variance (Fig. 5). Significant differences were found at the early time points $(1,2$, and 4 weeks, component 1) and at time point of 30 weeks (component 2). At the early time points of sampling, plant-litterderived ${ }^{13} \mathrm{C}$ was mainly found in PLFA $18: 3$ in the L.corniculatus treatments; increased values of PLFA $18: 2 \omega 6,9$ were found in $C$. epigejos treatments. At the latest sampling time points, high amounts of ${ }^{13} \mathrm{C}$ label were again measured in PLFA $18: 2 \omega 6,9$ for $C$. epigejos treatments and increased values for PLFAs a15:0, n16:0 and i15:0 for L. corniculatus treatments. 


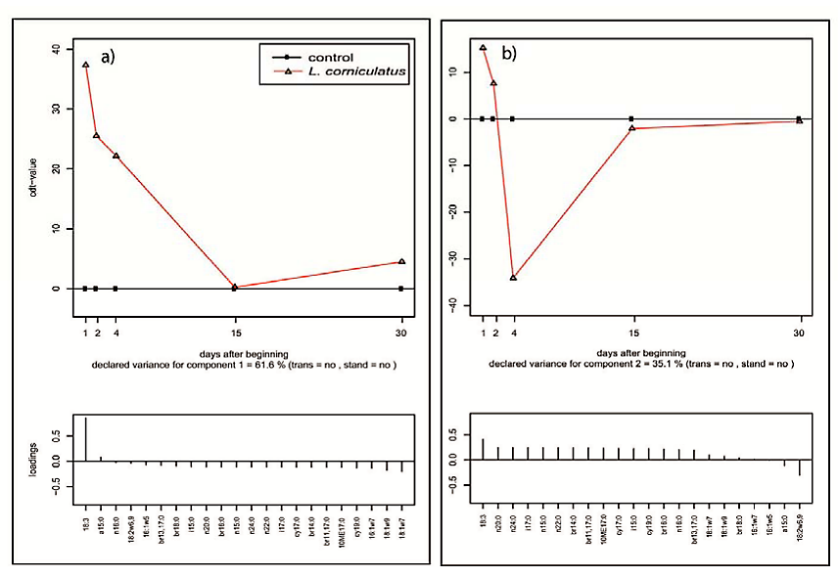

Fig. 3. First (a) and second (b) component of the PRC calculation on the basis of the mol \% data of all individual PLFA relative to total PLFA of $L$. corniculatus treatments compared to the control treatment throughout the experimental period of 30 weeks $(n=5)$.

\section{Discussion}

\subsection{Plant litter degradation}

During the experimental period of 30 weeks, a significant portion of the applied plant litter of $L$. corniculatus as well as $C$. epigejos had been degraded. However, the total loss of litter mass was lower in the field study than in a comparable microcosm experiment (Esperschütz et al., 2011), which indicates the importance of climatic conditions for the degradation of plant-derived litter material. Whereas in the microcosm study optimal conditions were chosen for litter degradation (including soil water content and temperature), these parameters are highly dynamic in time under field conditions. Mainly at the end of the incubation period (starting 21 weeks after addition of the plant litter material) temperature dropped significantly and soil moisture contents were lower than $30 \%$ of the maximum water holding capacity. These conditions may have influenced the degradation of the plant litter material in this phase (see Fig. S1 and Table S1, supplemental material). Compared to welldeveloped soils, processes and turnover rates in the soil material of the "Chicken Creek" catchment are apparently linked to the direct climatic conditions present at the site due to the low capacity to store water. Thus, the low precipitation during the autumn period might have a stronger influence on the degradation of plant litter compared to other sites with more developed soil ecosystems. Decomposition rates of litter mainly depend on the ratio of easily degradable substances to more recalcitrant compounds or substances with antimicrobial properties (Berg et al., 2000; Palosuo et al., 2005). C. epigejos litter was initially lower in N content but similar in its $\mathrm{C}$ content compared to the $L$. corniculatus plant litter. The high $\mathrm{C} / \mathrm{N}$ ratio of $C$. epigejos was apparently less attractive for microbial degraders mainly as ammonia and ni- trate concentrations in the soil samples were low or below the detection limit (data not shown), which confirms our initial hypothesis. Consequently, during the first four weeks of incubation the fast degradation rates of $L$. corniculatus plant litter might be linked to large amounts of water soluble plant litter components, rich in nitrogen content. Those compounds could be used by microbes colonising the litter material to increase their activity and biomass (Aneja et al., 2006; Poll et al., 2008). Hopkins et al. (2007) postulated a close link between decomposition rates of plant litter and nutritional quality in volcanic soils with a nutrient status comparable to the initial sites of "Chicken Creek". During the course of litter degradation, the ratio of easily degradable compounds to more complex compounds decreases for both litter materials; thus degradation rates slow down significantly. Again the specific properties of "young" soils may influence degradation in this phase more than in well-developed soils, as degradation of lignin and lignocellulose requires well-developed microbial network structures as well as a high nutrient status of the soil, both properties which do exist to only a limited degree in developing soils

\subsection{WEOC and total soil microbial biomass}

An increase in WEOC was detected in all litter treatments within one week of litter application (Fig. 2a). The parallel increase in ${ }^{13} \mathrm{C}$ in the WEOC indicated that this increase can be directly linked to the applied litter material (Fig. 3c). These results suggest a fast translocation of readily available organic $\mathrm{C}$ into the WEOC fraction. After one week of litter incubation, rainfall (Fig. S1) might have increased the transformation of plant-litter-derived C compounds into the WEOC fraction of soil, since plant residues may contain up to $25 \%$ water-soluble materials (Swift et al. 1979). After two weeks, the high WEOC content in the L. corniculatus treatments decreased and no statistically significant differences were detected between $L$. corniculatus and $C$. epigejos, neither in the absolute content (Fig. 3a) nor the litter-derived ${ }^{13} \mathrm{C}$ proportion (Fig. $2 \mathrm{c}$ ). This might be explained by a higher microbial biomass and activity in the L. corniculatus treatments (Fig. 2b and d), which incorporated most of the easily degradable plant-litter-derived carbon.

At 15 weeks after litter application, no differences in WEOC and microbial biomass or its corresponding ${ }^{13} \mathrm{C}$ signatures could be detected between the control treatment and both litter treatments; hence readily available $\mathrm{C}$ might have been leached within the soil matrix to deeper soil layers of the cylinders that were not analysed or into the surrounding soil.

\subsection{Soil microbial community profile and ${ }^{13} \mathrm{C}$ incorporation}

According to the PRC analyses, high proportions of $18: 3$ polyunsaturated fatty acids were dominating the 

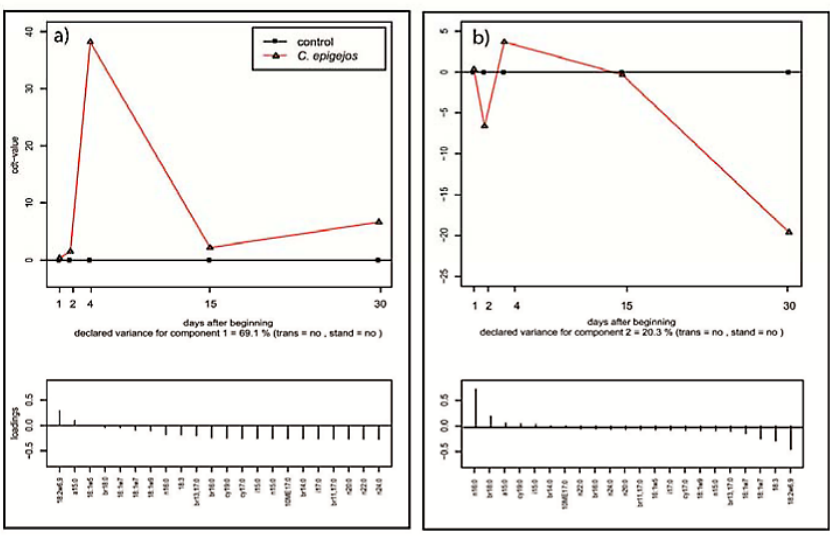

Fig. 4. First (a) and second (b) component of the PRC calculation on the basis of the mol \% data of all individual PLFA relative to total PLFA of $C$. epigejos treatments compared to the control treatment throughout the experimental period of 30 weeks $(n=5)$.

L. corniculatus treatment immediately after litter application (Fig. 3), which indicates high proportions of eukaryotes at this stage of litter degradation being involved in the transformation (Zelles et al., 1995; Ruess et al., 2007). This is also confirmed by the high ${ }^{13} \mathrm{C}$ signature in the corresponding fatty acid (Fig. 5). As the amount of litter material that had not been removed before lipid extraction was $<0.3 \%$, the amount of $18: 3$ derived from plant litter material is negligible. As we measured phospholipid fatty acids (PLFA) rather than pure neutral lipids, a high content of "free" PLFA as a result of organic matter flow from degraded plant material into the soil is quite unlikely. Zelles et al. (1999) calculated the average half-time of free PLFA in soil to less than 1 day due to its high energy status and subsequent fast degradation. Thus we think that the measurement of an individual PLFA is strongly connected to specific organisms they are indicative of, and hypothesise that these fatty acids are linked to microeukaryotes (Zelles et al., 1995; Ruess and Chamberlain, 2010). PLFA $18: 2 \omega 6,9$ and a15:0, which were also increased in abundance and in their specific ${ }^{13} \mathrm{C}$ label, illustrated a high contribution of soil fungi and Gram-positive bacteria mainly between two and four weeks after litter application in the degradation, which confirms studies by Poll et al. (2008) and Esperschütz et al. (2011). A limited soil $\mathrm{N}$ content in the substrate may have stimulated fungi to use plant-derived nitrogen (Fig. 3), as suggested earlier in an experiment using a similar substrate (Esperschütz et al., 2011). After 15 weeks of litter incubation, the microbial community structure detected in the $L$. corniculatus litter treatment was similar to the control treatments without litter addition, indicating that most of the introduced plant-derived carbon litter had already been utilized by the microbial biomass.

As for $L$. corniculatus treatments, fungi $(18: 2 \omega 6,9)$ and Gram-positive bacteria (a15:0) in treatments with C. epigejos benefited from the new plant-litter-derived $\mathrm{C}$ and $\mathrm{N}$; how-
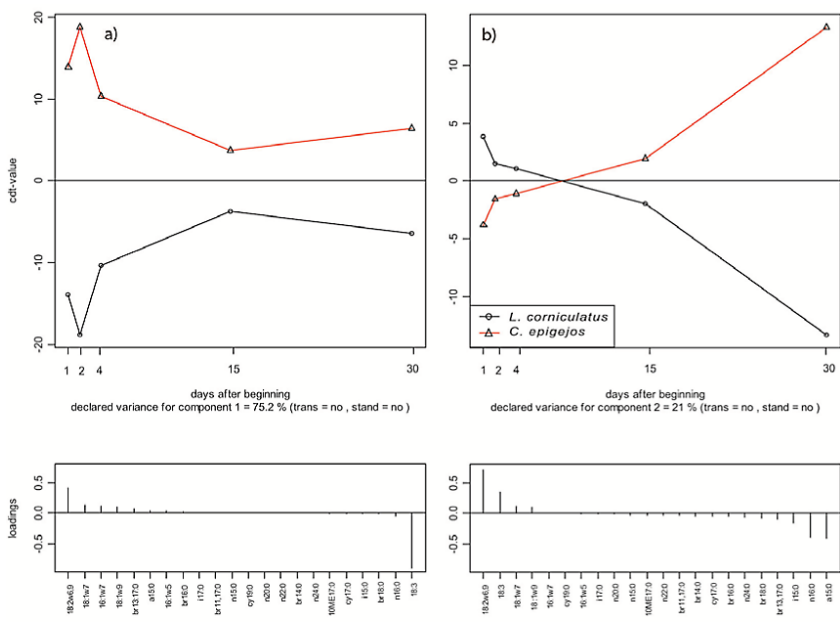

Fig. 5. First (a) and second (b) component of the PRC calculation on the basis of the percentage distribution of litter ${ }^{13} \mathrm{C}$ within the PLFA composition in C. epigejos and L. corniculatus throughout the experimental period of 30 weeks $(n=5)$.

ever, the increase in abundance was delayed compared to the treatments where L. corniculatus was applied and only emerged 4 weeks after litter application (Fig. 4), which might be related to the low availability of $\mathrm{N}$ and other nutrients in the soil. Again the increase in the ${ }^{13} \mathrm{C}$ signature in the corresponding fatty acids confirmed the role of these microbes in the plant litter decomposition process (Fig. 5). Obviously only small amounts of readily available $\mathrm{C}$ were provided by the C. epigejos plant litter, hence Gram-negative bacteria decreased over time. After 30 weeks of incubation, an increase of $18: 2 \omega 6,9$ and $\mathrm{a} 15: 0$ on PC1 and $18: 2 \omega 6,9,18: 3$, $16: 1 \omega 7$ and $18: 1 \omega 7$ on PC2 for $C$. epigejos indicated a microbial decomposer community which is able to degrade plant litter compounds which can be considered as more recalcitrant (Kuzyakov et al., 2000; Rubino et al. 2010), which was not present in L. corniculatus. It appears that in $L$. corniculatus treatments, the microbial community adapted to the high amounts of readily available $\mathrm{C}$ and $\mathrm{N}$ sources. In contrast to that, the recalcitrant plant litter favoured the development of a complex and sustainable microbial community structure capable of utilizing diverse $\mathrm{C}$ sources, even after readily available $\mathrm{C}$ compounds have been degraded.

Fungi seem to play an important role in the initial phase of litter degradation of the poorer substrates of $C$. epigejos treatments, which confirms results from a previous experiment (Esperschütz et al., 2011). The high ${ }^{13} \mathrm{C}$ content within the fungal biomass after two weeks of incubation (Fig. 5) might be a result of fungal hyphae which were grown from the mineral soil layer into the litter (Moore-Kucera and Dick, 2008), and subsequently provide nutrient sources for other organisms. However, recalcitrant $\mathrm{N}$ components may have stimulated fungi and at the end of the experiment may have outcompeted Gram-positive bacteria. Both groups of 
microbes have been described also in other studies in connection with the degradation of complex substrates (Kuzyakov et al., 2000; Dilly et al., 2004; de Boer et al., 2005; Rubino et al., 2010).

\section{Conclusions}

The kinetics of colonisation and the subsequent activity of the microbial communities in the detritusphere are strongly linked to the availability of $\mathrm{N}$. In early succession sites with poorly developed soil structures, plant litter represents a significant source of $\mathrm{N}$ for microbial organisms. In this study the higher $\mathrm{C} / \mathrm{N}$ ratio in $C$. epigejos plant litter resulted in lower microbial biomass and hence slower litter degradation rates mainly in the initial phase of litter degradation. At later stages, $\mathrm{N}$ was provided by recalcitrant $\mathrm{N}$ compounds, which induced a stimulation of microbes. More readily available $\mathrm{N}$ compounds in the litter of $L$. corniculatus allowed enhanced microbial growth already at the early stages of decomposition. Therefore, different pioneering plants sustain the nutritional $(\mathrm{N})$ state of the initially poor substrate. In the case of $L$. corniculatus, the amount of $\mathrm{N}$ provided by litter may result in the creation of nutrient-rich patches in the initially poor substrate material. Such nutrient-rich environments may stimulate colonisation with coexisting plants like C. epigejos, as they are known to tolerate nutrient-poor soil conditions for a long time, but can grow fast under N-rich conditions (Brezina et al., 2006; Tůma et al., 2009).

The lack of critical nutrients such as nitrogen (but probably also, for example, phosphorous) clearly impacts transformation rates of litter material and hence the generation of stable $\mathrm{C}$ pools in soil during ecosystem development. Whether fertilization of the plots or deliberate cultivation with plants with a low $\mathrm{C} / \mathrm{N}$ ratio (e.g. legumes) can promote this process remains an open question. Here research is needed, mainly to transform the knowledge on the role of different plant litter types into the development of practical applications for soil restoration.

\section{Supplementary material related to this article is available online at: http://www.biogeosciences.net/10/ 5115/2013/bg-10-5115-2013-supplement.pdf.}

Acknowledgements. The authors thank C. Kollerbaur for the PLFA extraction and S. Gamrath/I. Schicha for $\mathrm{CaCl}_{2}$ extraction; A. Lang is acknowledged for the technical support and the construction of experimental equipment. This study is part of the Transregional Collaborative Research Centre 38 (SFB/TRR 38), which is financially supported by the Deutsche Forschungsgemeinschaft (DFG, Bonn) and the Brandenburg Ministry of Science, Research and Culture (MWFK, Potsdam). The authors also thank Vattenfall Europe Mining AG for providing the research sites and experimental areas and C. Rißmann, K. Kleineidam and S. Schulz for their support preparing the sites for the present experiment. Finally, we wish to thank Jens-Arne Subke for his very helpful detailed suggestions for improvement.

Edited by: J.-A. Subke

\section{References}

Abrajano, J. T. A., Murphy, D. E., Fang, J., Comet, P., and Brooks, J. M.: ${ }^{13} \mathrm{C} /{ }^{12} \mathrm{C}$ ratios in individual fatty acids of marine mytilids with and without bacterial symbionts, Org. Geochem, 21, 611617, 1994.

Aneja, M., Sharma, S., Schloter, M., and Munch, J. C.: Microbial degradation of beech litter - Influence of soil type and litter quality on the structure and function of microbial populations involved in the turnover process, Microb. Ecol, 52, 127-135, 2006.

Bardgett, R. D. and Walker, L. R.: Impact of coloniser plant species on the development of decomposer microbial communities following deglaciation, Soil Biol. Biochem, 36, 555-559, 2004.

Bardgett, R. D., Mawdsley, J. L., Edwards, S., Hobbs, P. J., Rodwell, J. S., and Davies, W. J.: Plant species and nitrogen effects on soil biological properties of temperate upland grasslands, Funct. Ecol, 13, 650-660, 1999.

Baudoin, E., Benizri, E., and Guckert, A.: Impact of artificial root exudates on the bacterial community structure in bulk soil and maize rhizosphere, Soil Biol. Biochem, 35, 1183-1192, 2003.

Berg, B.: Litter decomposition and organic matter turnover in northern forest soils, Forest Ecol. Manag., 133, 13-22, 2000.

Brezina, S., Koubek, T., Münzbergová, Z., and Herben, T.: Ecological benefits of integration of Calamagrostis epigejos ramets under field conditions, Funct. Ecol. Plants, 201, 461-467, 2006.

de Boer, W., Folman, L. B., Summerbell, R. C., and Boddy, L.: Living in a fungal world: impact of fungi on soil bacterial niche development, FEMS Microb. Rev, 29, 795-811, 2005.

Dilly, O., Bloem, J., Vos, A., and Munch, J. C.: Bacterial diversity in agricultural soils during litter decomposition, Appl. Env. Microbiol, 70, 468-474, 2004.

DIN ISO 10390: Determination of pH. Berlin, Germany, Beuth Verlag $\mathrm{GmbH}, 1997$.

Eiland, F., Klamer, M., Lind, A. M., Leth, M., and Bååth, E.: Influence of Initial C/N Ratio on Chemical and Microbial Composition during Long Term Composting of Straw, Microb. Ecol, 41, 272-280, 2001.

Elfstrand, S., Lagerlöf, J., Hedlund, K., and Mårtensson, A.: Carbon routes from decomposing plant residues and living roots into soil food webs assessed with ${ }^{13} \mathrm{C}$ labelling, Soil Biol. Biochem, 40, 2530-2539, 2008.

Esperschütz, J., Buegger, F., Winkler, J. B., Munch, J. C., Schloter, M., and Gattinger, A.: Microbial response to exudates in the rhizosphere of young beech trees (Fagus sylvatica L.) after dormancy, Soil Biol. Biochem, 41, 1976-1985, 2009.

Esperschütz, J., Welzl, G., Schreiner, K., Buegger, F., Munch, J. C., and Schloter, M.: Incorporation of carbon from decomposing litter of two pioneer plant species into microbial communities of the detritusphere, FEMS Microb. Let, 320, 48-55, 2011.

Fioretto, A., Di Nardo, C., Papa, S., and Fuggi, A.: Lignin and cellulose degradation and nitrogen dynamics during decomposition of 
three leaf litter species in a Mediterranean ecosystem, Soil Biol. Biochem, 37, 1083-1091, 2005.

Fraser, L. H. and Hockin, A. D.: Litter decomposition rates of two grass species along a semi-arid grassland-forest ecocline, J. Arid Env., 88, 125-129, 2013.

Frey, S. D. and Elliott, E. T.: Reciprocal transfer of carbon and nitrose by decomposer fungi at the soil - litter interface, Soil Biol. Biochem, 35, 1001-1004, 2003.

Gerwin, W., Schaaf, W., Biemelt, D., Fischer, A., Winter, S., and Hüttl, R. F.: The artificial catchment "Chicken Creek" (Lusatia, Germany) - A landscape laboratory for interdisciplinary studies of initial ecosystem development, Ecol. Eng., 35, 1786-1796, 2009.

Gschwendtner, S., Esperschütz, J., Buegger, F., Reichmann, M., Müller, M., Radl, V., Munch, J. C., and Schloter, M.: Effects of a genetically modified starch metabolism in potato plants on photosynthate fluxes into the rhizosphere and on microbial degraders of root exudates; FEMS Microb. Ecol., 76, 564-575, 2011

Hättenschwiler, S., Tiunov, A. V., and Scheu, S.: Biodiversity and Plant litter decomposition in terrestrial ecosystems, Annu. Rev. Ecol, 36, 191-218, 2005.

Hoagland, D. R.: Optimum nutrient solution for plants, Science, 52, 562-564, 1920

Hopkins, D., Badalucco, L., English, L., Meli, S., Chudek, J., Ioppolo, A.: Plant litter decomposition and microbial characteristics in volcanic soils (Mt Etna, Sicily) at different stages of development, Biol. Fertil. Soils, 43, 461-469, 2007.

Krummen, M., Hilkert, A. W., Juchelka, D., Duhr, A., Schlüter, H.J., and Pesch, R.: A new concept for isotope ratio monitoring liquid chromatography/mass spectrometry, Rap. Com. Mass Spect. 18, 2260-2266, 2004.

Kurzatkowski, D., Martius, C., Höfer, H., Garcia, M., Förster, B., Beck, L., and Vlek, P.: Litter decomposition, microbial biomass and activity of soil organisms in three agroforestry sites in central Amazonia, Nutr. Cycl. Agroecosys., 69, 257-267, 2004.

Kuzyakov, Y., Friedel, J. K., and Stahr, K.: Review of mechanisms and quantification of primingproming effects, Soil Biol. Biochem., 32, 1485-1498, 2000.

Marx, M., Buegger, F., Gattinger, A., Marschner, B., Zsolnay, A., and Munch, J. C.: Determination of the fate of ${ }^{13} \mathrm{C}$ labelled maize and wheat rhizodeposit- $\mathrm{C}$ in two agricultural soils in a greenhouse experiment under ${ }^{13} \mathrm{C}-\mathrm{CO}_{2}$-enriched atmosphere, Soil Biol. Biochem., 39, 3043-3055, 2007.

Moore-Kucera, J. and Dick, R. P.: Application of ${ }^{13} \mathrm{C}$-labeled litter and root materials for in situ decomposition studies using phospholipid fatty acids, Soil Biol. Biochem., 40, 2485-2493, 2008.

Palosuo, T., Liski, J., Trofymow, J. A., and Titus, B. D.: Litter decomposition affected by climate and litter quality-Testing the Yasso model with litterbag data from the Canadian intersite decomposition experiment, Ecol. Mod., 189, 183-198, 2005.

Pawlowska, T. E., Błaszkowski, J., and Rühling, Å.: The mycorrhizal status of plants colonizing a calamine spoil mound in southern Poland, Mycorrhiza, 6, 499-505, 1997.

Poll, C., Marhan, S., Ingwersen, J., and Kandeler, E.: Dynamics of litter carbon turnover and microbial abundance in a rye detritusphere, Soil Biol. Biochem., 40, 1306-1321, 2008.
Rubino, M., Dungait, J. A. J., Evershed, R. P., Bertolini, T., De Angelis, P., D’Onofrio, A., Lagomarsino, A., Lubritto, C., Merola, A., Terrasi, F., and Cotrufo, M. F.: Carbon input belowground is the major $\mathrm{C}$ flux contributing to leaf litter mass loss: Evidences from a ${ }^{13} \mathrm{C}$ labelled-leaf litter experiment, Soil Biol. Biochem., 42, 1009-1016, 2010.

Ruess, L. and Chamberlain, P. M.: The fat that matters: Soil food web analysis using fatty acids and their carbon stable isotope signature, Soil Biol. Biochem., 42, 1898-1910, 2010.

Ruess, L. Schütz, K., Migge-Kleian, S., Häggblom, M. M., Kandeler, E., and Scheu, S.: Lipid composition of Collembola and their food resources in decidious forest stands - implictions for feeding stragtegies, Soil Biol. Biochem., 39, 1990-2000, 2007.

Schaaf,, W., Bens, O., Fischer, A., Gerke, H. H., Gerwin, W., Grünewald, U., Holländer, H. M., Kögel-Knabner, I., Mutz, M., Schloter, M., Schulin, R., Veste, M., Winter, S., and Hüttl, R. F.: Patterns and processes of initial terrestrial-ecosystem development, J. Plant Nutr. Soil Sci., 174, 229-239, 2011.

Schramm, K.-W., Jaser, W., Welzl, G., Pfister, G., WöhlerMoorhoff, G., and Hense, B. A.: Impact of $17 \alpha$-ethiylestradiol on the plankton in freshwater microcosms I: Response of zooplankton and abiotic variables Ecotox, Env. Safety, 69, 437-452, 2007.

Süß, K., Storm, C., Zehm, A., and Schwabe, A.: Succession in inland sand ecosystems: which factors determine the occurrence of the tall grass species Calamagrostis epigejos (L.) Roth and Stipa capillata L., Plant Biol. 6, 465-476, 2004.

Swift, M., Heal, O., and Anderson, J.: Decomposition in terrestrial ecosystems, Blackwell Publishers, Oxford, 1979.

Tůma, I., Holub, P., and Fiala, K.: Soil nutrient heterogeneity and competitive ability of three grass species Festuca ovina, Arrhenatherum elatius and Calamagrostis epigejos in experimental conditions, Biologia, 64, 694-704, 2009.

Van den Brink, P. J. and ter Braak, C. J. F.: Principal response curves: Analysis of time-dependent multivariate responses of biological community to stress, Env. Tox. Chem, 18, 138$148,1999$.

Van Veen, J. and Kuikman, P.: Soil structural aspects of decomposition of organic matter by micro-organisms, Biogeochemistry, 11, 213-233, 1990.

Walker, T. S., Bais, H. P., Grotewold, E., and Vivanco, J. M.: Root Exudation and Rhizosphere Biology, Plant Physiol., 132, 44-51, 2003.

Wardle, D. A., Bardgett, R. D., Klironomos, J. N., Setälä, H., van der Putten, W. H., and Wall, D. H.: Ecological linkages between aboveground and belowground biota, Science, 304, 1629-1633, 2004.

Zelles, L.: Fatty acid patterns of phospholipids and lipopolysaccharides in the characterisation of microbial communities in soil: a review, Biol. Fertil. Soils, 29, 111-129, 1999.

Zelles, L., Bai, Q. Y., Rackwitz, R., Chadwick, D., and Beese, F.: Determination of phospholipid- and lipopolysaccharide-derived fatty acids as an estimate of microbial biomass and community structure in soils, Biol. Fertil. Soil, 19, 115-123, 1995. 